\title{
Evaluation of Chemical Properties, Amino Acid Contents and Fatty Acid Compositions of Sesame Seed Provided from Different Locations
}

\author{
Isam A Mohamed Ahmed ${ }^{1}$, Fahad AlJuhaimi ${ }^{1}$, Mehmet Musa Özcan²* , Kashif Ghafoor ${ }^{1}$, \\ Şenay Şimşek ${ }^{3}$, Elfadıl E Babiker ${ }^{1}$, Magdi A. Osman ${ }^{1}$, Mustafa A. Gassem¹, and \\ Hesham A. A. Salih ${ }^{1}$ \\ ${ }^{1}$ Department of Food Science and Nutrition, College of Food and Agricultural Sciences, King Saud University, Riyadh, SAUDI ARABIA \\ ${ }^{2}$ Department of Food Engineering, Faculty of Agriculture, University of Selçuk, 42031 Konya, TURKEY \\ ${ }^{3}$ Department of Plant Sciences, Cereal Science Technology, North Dakota State University, Fargo, USA
}

\begin{abstract}
In this study, chemical properties, amino acid contents, fatty acid compositions of sesame seeds dependin on growing locations of sesame plants were evaluated. Protein contents of sesame seeds changed between $\mathbf{2 0 . 8 0 \%}$ (Afghanistan) and $\mathbf{2 6 . 0 1 \%}$ (India). Oil contents of seeds were changed between $\mathbf{4 4 . 6 9 \%}$ (Mozambique) and $\mathbf{5 5 . 3 7 \%}$ (Niger-Kany). Crude fiber contents of sesame seeds ranged from $\mathbf{1 7 . 3 0 \%}$ (Ethiopia-Volega) to $\mathbf{2 8 . 7 8 \%}$ (Mozambique). The highest protein, crude oil and crude fiber were found in India, Niger-Kany and Mozambique sesame seed samples, respectively. In addition, while glutamic acid contends of seeds change between 3.28\% (Uganda and Niger-Benje) and $4.57 \%$ (India), arginine contents of seeds ranged from $2.36 \%$ (Uganda) to $3.10 \%$ (India). The total amino acid contents of sesame seeds ranged from $\mathbf{1 8 . 1 2 \%}$ (Uganda) to $\mathbf{2 3 . 5 1 \%}$ (India). Palmitic acid contents of sesame oils ranged from $\mathbf{7 . 9 3 \%}$ (Uganda) to 9.55\% (Burkina Faso). While oleic acid contents of sesame seed oils are found between $35.88 \%$ (Mozambique) and $44.54 \%$ (Afghanistan), linoleic acid contents of oils ranged from $37.41 \%$ (Afghanistan) to $47.44 \%$ (Mozambique). The high amount of protein, oil contents, amino acids and unsaturated fatty acids can be positively considered from the nutritional point of view.
\end{abstract}

Key words: sesame, proximate, amino acid, fatty acid, GC

\section{Introduction}

Sesame (Sesamum indicum L.) is one of the most important plant in oil seed $\mathrm{crop}^{1,2)}$. Sesame is an excellent edible oil and protein ${ }^{3,4)}$. In general, the oil contents of the cultivars were found within the range reported for sesame seed cultivars grown in various parts of the world. Due to its high oil yield, mildness and pleasant taste sesame is named as the queen of the oilseeds crops ${ }^{4-7)}$. Sesame seed is cultivated on a world wide basis for both oil and protein $^{8)}$. Sesame seeds are used in the making of tahin (Sesame butter) and halva, and fort he preparation of rolls, crackers, cakes and pastry products in commercial bakeries. Sesame is mostly utilized as a whole seed throughout the world in condiments or as an additives on breads, biscuits and other confectionery product. Sesame is used in condiments $^{2,9-11)}$. The variety, origin, color and size of sesame seed affect to the chemical composition of sesame seed and its oil. Plant seeds are important sources of oils of nutritional, industrial and pharmaceutical importance. Although sesame oil contains unsaturated fatty acid, it is most resistant to oxidative rancidity among many vegetable oils ${ }^{12,13)}$. The fatty acid composition of oils plays an important role in determining shelf life and nutrition of food products. The main fatty acid in sesame oil is linoleic acid, followed by oleic, palmitic and stearic acid. These four fatty acids constitute a large proportion of the total fatty acid composition of sesame oil ${ }^{14-16)}$. Therefore, the purpose of the current study was to determine chemical properties, amino acid, fatty acid compositions of sesame seeds dependin on growing locations of sesame plants.

\footnotetext{
*Correspondence to: M. M. Özcan, Department of Food Engineering, Faculty of Agriculture, University of Selçuk, 42031 Konya, TURKEY

E-mail: iali@ksu.edu.sa, mozcan@selcuk.edu.tr

Accepted April 3, 2020 (received for review February 16, 2020)

Journal of Oleo Science ISSN 1345-8957 print / ISSN 1347-3352 online

http://www.jstage.jst.go.jp/browse/jos/ http://mc.manusriptcentral.com/jjocs
} 


\section{Material and Methods}

\subsection{Material}

Sesame (Sesamum indicum L.) seeds belong to several countries (Afghanistan, Burkina Faso, Ethiopia-Volega, Ethiopia-Humera, Mozambique, Niger-Benje, Niger-Wadaguri, Uganda, Niger-Kany and India) were purchased from a local market in Saudi Arabia (Riyadh). They were sorted to remove any dirt or foreign material present in them. Each parameter is the mean of three replicate determinations.

\subsection{Methods}

\subsubsection{Proximate Analysis}

Determination of moisture and protein content was done according to AACC (44-15.02 and 46-30.01). Moisture was measured by heating the sample for 1 hour at $135^{\circ} \mathrm{C}$ in a gravity oven ${ }^{17)}$. The nitrogen combustion method was used for determination of crude protein. The protein determination was made in Leco combustion analyzer and 6.25 was used as the conversion factor ${ }^{18)}$. Total starch was measured using AACC approved method 76-13.01, using an assay kit from Megazyme (Megazyme International, Ireland). The samples were incubated with heat stable fungal $\alpha$-amylase and amyloglucosdiase to hydrolyze the starch to glucose. The glucose was treated with glucose oxidase/peroxidase (GOPOD) and the absorbance was read at $492 \mathrm{~nm}$. The starch content was calculated based on the glucose concentration $^{19)}$. Crude oil content was determined by ether extraction, according to AOAC Official Method 920.39(A) and crude fiber content was determined according to AOAC official method $978.10^{20)}$.

2.2.2 Amino acid profile

The amino acid contents of seeds were determined by using AOAC Official Method 982.30 E (a,b,c $)^{17)}$.

2.2.3 Fatty acid profile

The fatty acid methyl esters were identified by compar- ing the retention time of the samples and appropriate fatty acids methyl esters standards according to AOAC official methods 996.06[Analysis of methyl esters by Capillary GLC]. From the liquid phase on the top, $1 \mu \mathrm{L}$ the fatty acid methyl ester was injected in a gas chromotograph (GC/FID (HP-AGILENT/6890)) with a capillary column, CP-Sil 88 (100 m long, $0.25 \mathrm{~mm}$ ID, film thickness $0.2 \mu \mathrm{m})^{20)}$.

2.2.4 Statistical analysis

Analysis of variance (ANOVA) and mean \pm standard deviation (MSTAT C) of results were calculated according to Püskülcü and İkiz ${ }^{21)}$.

\section{Results and Discussion}

Physico-chemical properties of some sesame seeds provided from several countries are given in Table 1. Moisture contents of the sesame samples ranged from 3.99\% (NigerKany) to $4.98 \%$ (Ethiopia-Humera). In addition, while protein contents of sesame seeds change between $20.80 \%$ (Afghanistan) and $26.01 \%$ (India), ash contents of the samples varied between $4.41 \%$ (India) and $5.42 \%$ (NigerWadaguri) $(p<0.05)$. Oil contents of seeds were found high and changed between 44.69\% (Mozambique) and $55.37 \%$ (Nigeria-Kany). Crude fiber contents of sesame seeds ranged from $17.30 \%$ (Ethiopia -Volega) to $28.78 \%$ (Mozambique) $(p<0.05)$. The highest protein, crude oil and crude fiber were found in India, Niger-Kany and Mozambique sesame seed samples, respectively. Physicochemical properties of sesame seeds showed differences depending on several origins of sesame seeds. Our results were found similar with results (5.7\% moisture, $48.5 \%$ crude oil, $20 \%$ crude protein, $9.4 \%$ crude fiber and $4.2 \%$ ash) reported by Nzikou et al. ${ }^{1)}$. Borchani et $a l .{ }^{2)}$ reported that sesame seed contained $24.63 \%$ protein, $52.67 \%$ oil

Table 1 Proximate analysis of sesame seeds (\%).

\begin{tabular}{lccccc}
\hline & & \multicolumn{3}{c}{$\%$} \\
\cline { 3 - 6 } & Moisture & Protein & Ash & Crude oil & Crude fiber \\
\hline Afghanistan & $4.03 \pm 0.45^{*} \mathrm{c}$ & $20.80 \pm 1.17 \mathrm{~d}$ & $4.86 \pm 0.21 \mathrm{~b}$ & $54.25 \pm 2.33 \mathrm{a}$ & $18.01 \pm 0.56 \mathrm{~d}$ \\
Burkina Faso & $4.54 \pm 0.38 \mathrm{c}^{* *}$ & $22.34 \pm 1.09 \mathrm{~b}$ & $5.27 \pm 0.17 \mathrm{a}$ & $53.36 \pm 1.78 \mathrm{~b}$ & $17.75 \pm 1.18 \mathrm{e}$ \\
India & $4.68 \pm 0.67 \mathrm{~b}$ & $26.01 \pm 1.23 \mathrm{a}$ & $4.41 \pm 0.48 \mathrm{~b}$ & $50.18 \pm 2.17 \mathrm{c}$ & $18.18 \pm 0.98 \mathrm{~d}$ \\
Mozambique & $4.60 \pm 0.51 \mathrm{~b}$ & $22.97 \pm 1.27 \mathrm{~b}$ & $5.24 \pm 0.38 \mathrm{a}$ & $44.69 \pm 2.21 \mathrm{~d}$ & $28.78 \pm 0.55 \mathrm{a}$ \\
Uganda & $4.70 \pm 0.44 \mathrm{~b}$ & $21.34 \pm 0.98 \mathrm{c}$ & $5.10 \pm 0.48 \mathrm{a}$ & $54.01 \pm 1.56 \mathrm{a}$ & $22.34 \pm 1.52 \mathrm{~b}$ \\
Ethiopia - Humera & $4.98 \pm 0.63 \mathrm{a}$ & $22.98 \pm 1.26 \mathrm{~b}$ & $4.68 \pm 0.53 \mathrm{~b}$ & $52.52 \pm 1.56 \mathrm{~b}$ & $22.53 \pm 1.32 \mathrm{~b}$ \\
Ethiopia - Volega & $4.85 \pm 0.47 \mathrm{a}$ & $22.05 \pm 1.11 \mathrm{~b}$ & $5.18 \pm 0.47 \mathrm{a}$ & $52.19 \pm 1.38 \mathrm{~b}$ & $17.30 \pm 1.45 \mathrm{e}$ \\
Niger - Benje & $4.61 \pm 0.33 \mathrm{~b}$ & $21.99 \pm 1.34 \mathrm{c}$ & $4.98 \pm 0.41 \mathrm{~b}$ & $52.87 \pm 1.48 \mathrm{~b}$ & $18.52 \pm 1.28 \mathrm{~d}$ \\
Niger - Kany & $3.99 \pm 0.36 \mathrm{~d}$ & $21.89 \pm 1.42 \mathrm{c}$ & $4.77 \pm 0.38 \mathrm{~b}$ & $55.37 \pm 1.67 \mathrm{a}$ & $19.34 \pm 0.87 \mathrm{c}$ \\
Niger - Wadaguri & $4.20 \pm 0.53 \mathrm{c}$ & $22.46 \pm 1.19 \mathrm{~b}$ & $5.42 \pm 0.53 \mathrm{a}$ & $50.88 \pm 1.24 \mathrm{c}$ & $20.58 \pm 1.43 \mathrm{c}$ \\
\hline
\end{tabular}

*mean \pm standard deviation; **Values within each column followed by different letters are significantly different $(p<0.05)$. 


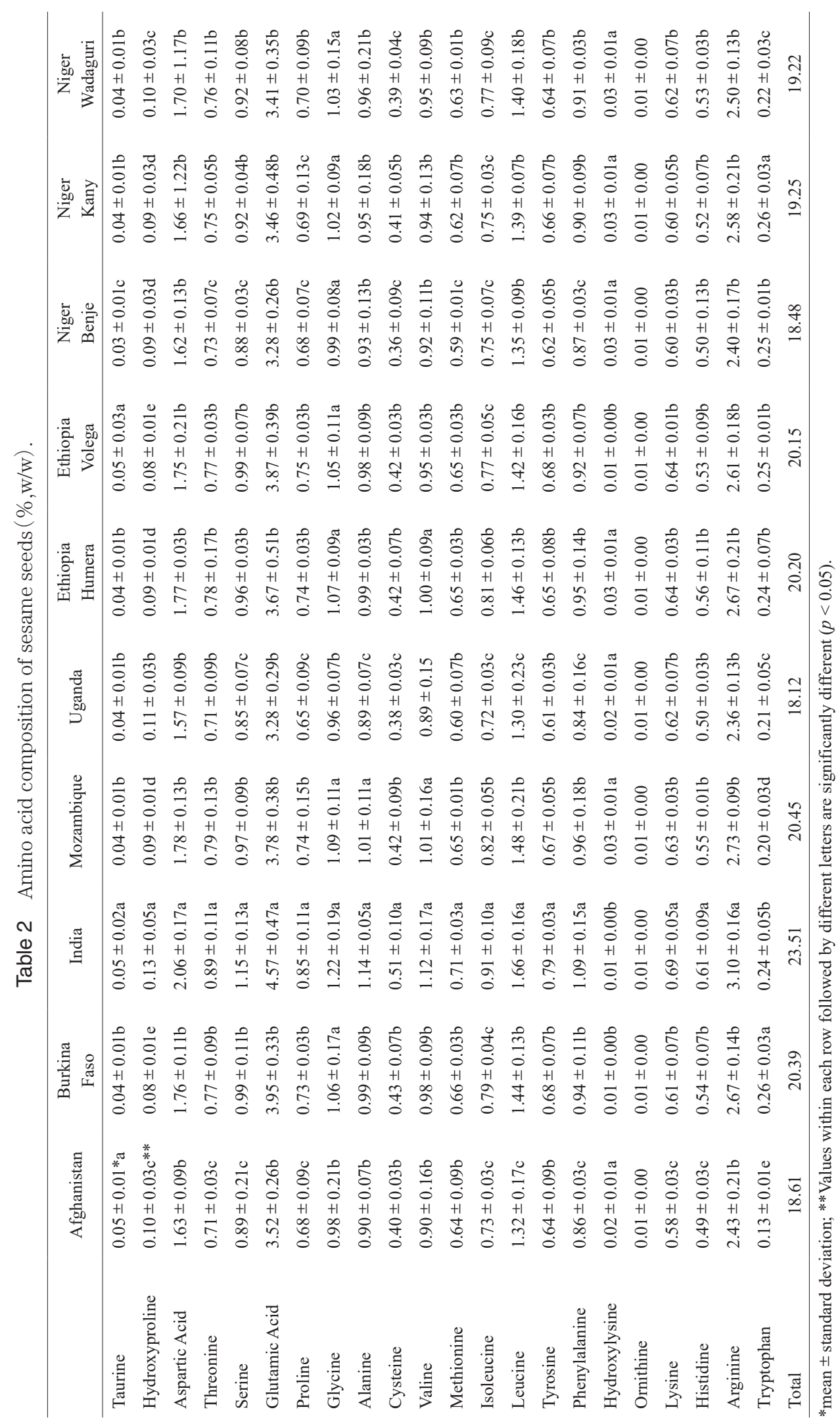




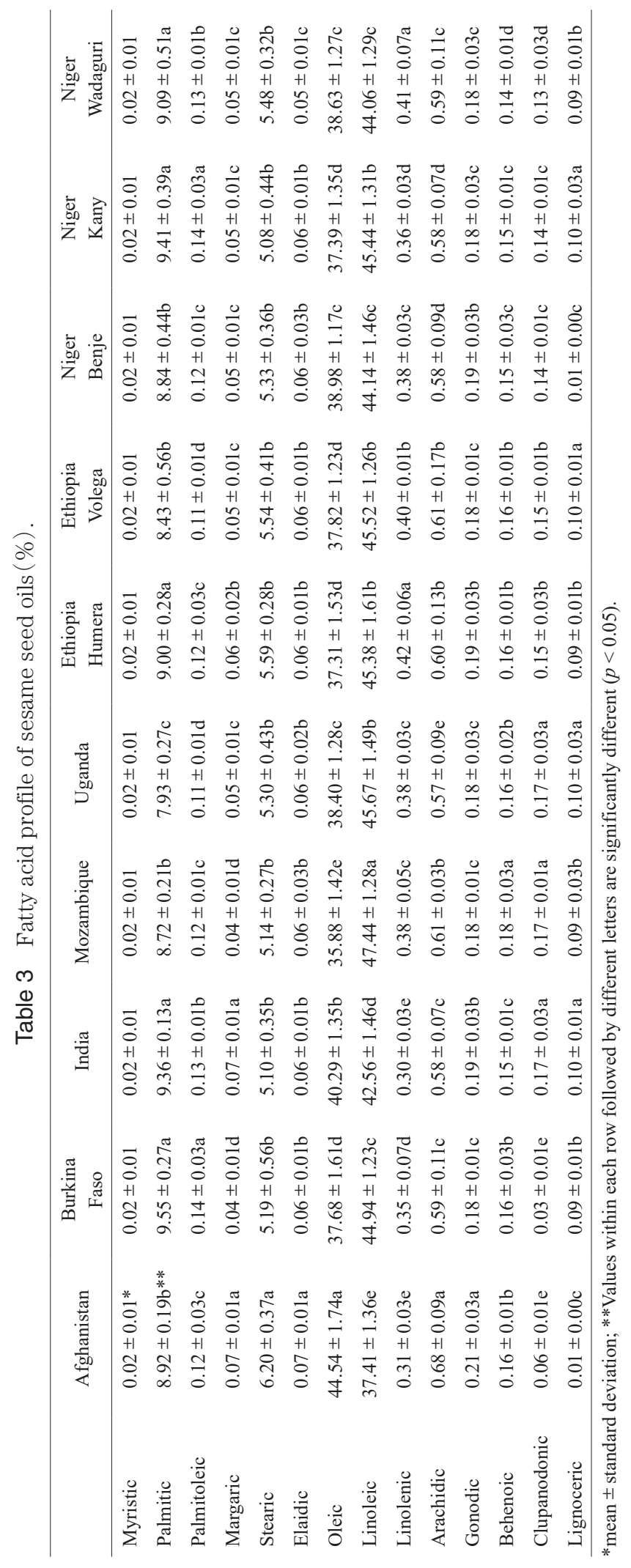


and $5.44 \%$ ash. Hassan ${ }^{22)}$ reported that roasted sesaseme seeds contained $0.20-3.06 \%$ moisture, $18.92-23.18 \%$ crude protein, $3.01-4.38 \%$ ash, $6.75-7.34 \%$ crude fiber and $56.49-59.97 \%$ crude oil. Sesame seeds contained 4.15$4.30 \%$ moisture, $18.96-22.55 \%$ protein, $3.01-3.6 \%$ fiber, $3.67-5.1 \%$ ash and $49.5-53.9 \% \mathrm{oil}^{23)}$. These differences in results can be probably due to growing locations, genetic factors, harvest time and analytical conditions.

Amino acid composition of sesame seeds are presented in Table 2. Generally, seeds rich in glutamic, aspartic, arginine and leucine amino acids. Amino acid contents of sesame seeds showed differences depending on growing locations of sesame seeds. The highest amino acid contents were detected in India sesame samples, followed by Mozambique, Burkina Faso, Ethiopia Humera and Ethiopia Volega in descending order. While glutamic acid contends of seeds change between 3.28\% (Uganda and Nigeria-Benje) and $4.57 \%$ (India), arginine contents of seeds ranged from $2.36 \%$ (Uganda) to $3.10 \%$ (India) $(p<0.05)$. Also, leucine contents of sesame seeds changed between $1.30 \%$ (Uganda) and $1.66 \%$ (India). In addition, aspartic acid contents of sesame seeds were found between $1.57 \%$ (Uganda) and 2.06\% (India). The total amino acid contents of sesame seeds ranged from $18.12 \%$ (Uganda) to $23.51 \%$ (India). As seen in Table 2, amino acid contents of sesame seeds provided from India were found higher than those of results of sesame provided from other countries.

Fatty acid compositions of sesame oils are reported in Table 3. Palmitic acid contents of sesame oils ranged from 7.93\% (Uganda) to $9.55 \%$ (Burkina Faso). It was observed statistically significant differences among fatty acid compositions of sesame seeds depending on locations $(p<0.05)$. As second saturated fatty acid, stearic acid contents of sesame oils were found between 5.08\% (Niger-Kany) and $6.20 \%$ (Afghanistan). In addition, while oleic acid contents of sesame seed oils were found between 35.88\% (Mozambique) and $44.54 \%$ (Afghanistan), linoleic acid contents of oils ranged from $37.41 \%$ (Afghanistan) to $47.44 \%$ (Mozambique) $(p<0.05)$. Other fatty acids of the samples were found in trace amounts. The highest palmitic, oleic and linoleic acids were identified in Burkina Faso, Afghanistan and Mozambique locations, respectively. In previous study, oil contents of sesame seeds were found between 49.5 and $53.9 \%{ }^{20)}$. The precentage content of caprilic, linoleic, palmitic and stearic acids in the sesame seed oils varied between $16.9-21.8 \%, 4.7-12.5 \%, 16.0-19.3 \%$ and 13.9 $21.5 \%$, respectively ${ }^{23}$. Sesame oil contained 35.9-47.0\% oleic, 35.6-47.6\% linoleic, 8.7-13.8\% palmitic, 2.1-6.4\% stearic acids ${ }^{4,24,25)}$. Borchani et $a .^{2}{ }^{2}$ reported that sesame seed oil contained $12.96 \%$ palmitic, $5.76 \%$ stearic, $41.68 \%$ oleic and $38.29 \%$ linoleic acids. Linoleic $(42.66-43.21 \%$ and oleic acids (39.22-41.63\%) were the main unsaturated fatty acids of sesame $\mathrm{oil}^{22}{ }^{22}$. The results obtained are in agreement with those reported by Özcan et $a{ }^{22}{ }^{22}$; Aued-Pimentel et $a l .{ }^{26)}$ and Borchani et $a l .{ }^{2}$. Özcan et $a l .{ }^{25)}$ determined $11.2 \%$ palmitic, $12.6 \%$ stearic, $41.9 \%$ oleic, $43.9 \%$ linoleic and $0.1 \%$ linolenic acids in sesaseme seed oil. Our results were found generally similar to literature values. It was also considered that biochemical differences of the varieties consisted of genetic variation and different harvest time.

\section{Conclusion}

Crude protein, crude fibre and crude oil contents of seeds were affected mainly by variety, locations and growing conditions. It may be concluded that these seed oils are suitable for edible purposes as it contain relatively higher amounts of unsaturated fatty acid, very close to those reported for the edible oils. Sesame seed and oils are worth attention as a source of health promoting component for foods. The high amount of unsaturated fatty acids can be positively considered from the nutritional point of view.

\section{Acknowledgements}

The authors extend their appreciation to the Deanship of Scientific Research at King Saud University for funding this work through research group no. (RG-1439-80).

\section{References}

1) Nzikou, J.M.; Matos, L.; Bouanga-Kalou, G.; Ndangui, C.B.; Pambou-Tobi, N.P.G.; Kimbonguila, A.; Silou, Th.; Linder, M.; Desobry, S. Chemical composition on the seeds and oil of sesame (Sesamum indicum L.) grown in Congo-Brazzaville. Advance J. Food Sci. Technol. 1, 6-11 (2009).

2) Borchani, C.; Besbes, S.; Blecker, C.; Attia, H. Chemical characteristics and oxidative stability of sesame seed, sesame paste, and olive oils. J. Agr. Sci. Technol. 12, 585-596 (2010).

3) Hamurcu, M.; Uslu, N.; Al-Juhaimi, F.; Özcan, M.M. Effect of some medicinal tea extracts on some oxidative parameters of sesame oil. Asian J. Chem. 25, 99019903 (2013).

4) Elleuch, M.; Besbes, S.; Roiseux, O.; Blecker, C.; Attia, H. Quality characteristics of sesame seeds and byproducts. Food Chem. 103, 641-650 (2007).

5) Yermanos, D.M.; Hemstreet, S.; Saleeb, W.; Huszar, C.K. Oil content and composition of the seed in the world collection of sesame Introductions. J. Am. Oil Chem. Soc. 49, 20-23 (1972).

6) Adebowale, A.A.; Sanni, S.A.; Falore, O.A. Varietal differences in the physical properties and proximate composition of elite sesame seeds. World J. Agric. 
Sci. 7, 42-46(2011).

7) Shyu, Y.S.; Hwang, L.S. Antioxidative activity of the crude extract of lignan glycosides from unroasted Burma black sesame meal. Food Res. Int. 35, 357-365 (2002).

8) Baydar, H.; Turgut, I.; Turgut, K. Variation of certain characters and line selection for yield, oleic and linoleic acid in the Turkish sesame (Sesamum indicum L.) populations. J. Agric. Forest. 23, 431-441 (1999).

9) Alyemeni, M.N.; Basahy, A.Y.; Sher, H. Physico-chemical analysis and mineral composition of some sesame seeds (Sesamum indicum L.) grown in the Gizan area of Saudi Arabia. J. Med. Plants Res. 5, 270-274(2011).

10) Kamal-Eldin, A.; Appelqvist, L.A.; Yousif, G. Lignan analysis in seed oils from four Sesamum species: Comparison of different chromatographic methods. $J$. Am. Oil Chem. Soc. 71, 141-147(1994).

11) Elleuch, M.; Besbes, S.; Roiseux, O.; Blecker, C.; Attia, H. Quality characteristics of sesame seeds and byproducts. Food Chem. 103, 641-650 (2007).

12) Yen, G.C.; Shyu, S.L. Oxidative stability of sesame oil prepared from sesame seed with different roasting temperatures. Food Chem. 31, 215-224(1989).

13) Abou-Gharbia, H.A.; Shehata, A.A.Y.; Shahidi, F. Effect of processing on oxidative stability and lipid classes of sesame oil. Food Res. Int. 33, 331-340 (2000).

14) Were, B.A.; Onkware, A.O.; Gudu, S.; Welander, M.; Carlsson, A.S. Seed oil content and fatty acid composition in East African sesame (Sesamum indicum L.) accessions evaluated over 3 years. Field Crops Res. 97, 254-260 (2006).

15) Yoshida, H. Composition and quality characteristics of sesame seed (Sesamum indicum) oil roasted at different temperature in an electric oven. J. Sci. Food Agric. 65, 331-336 (1994).

16) Targais, K.; Stobdan, T.; Yadav, A.; Bala Singh, S.B. Extraction of apricot kernel oil in cold desert Ladakh, India. Indian J. Trad. Know. 10, 304-306(2011).
17) AACC Approved Methods of Analysis, 11th Ed. Method 44-15.02. Moisture - Air-Oven Methods. Approved November 3, AACC International, St. Paul, MN, USA (1999).

18) AACC Approved Methods of Analysis, 11th Ed. Method 46-30.01. Crude Protein - Combustion Method. Approved November 3, AACC International, St. Paul, MN, $\operatorname{USA}(1999)$.

19) AACC Approved Methods of Analysis, 11th Ed. Method 76-13.01. Total Starch Assay Procedure (Megazyme Amyloglucosidase/alpha-Amylase Method). Approved November 3, AACC International, St. Paul, MN, USA (1999).

20) Horwitz, W.; Latimer, G.W. Official methods of analysis of $A O A C$ international. AOAC International (2006).

21) Püskülcü, H.; İkiz, F. Introduction to Statistic. Bilgehan Press, p. 333. Bornova, İzmir, Turkey(1989). (in Turkish).

22) Hassan, M.A.M. Studies on Egyptian sesame seeds (Sesamum indicum L.) and its products 1-Physicochemical analysis and phenolic acids of roasted Egyptian sesame seeds (Sesamum indicum L.). World J. Dairy Food Sci. 7, 195-201 (2012).

23) Asghar, A.; Majeed, M.N. Chemical characterization and fatty acid profile of different sesame varieties in Pakistan. Am. J. Sci. Ind. Res. 4, 540-545(2013).

24) Uzun, B.; Ülger, S.; Çagirgan, M.I. Comparison of determinate and indeterminate types of sesame for oil content and fatty acid composition. Turk. J. Agric. Forest. 26, 269-274(2002).

25) Özcan, M.M.; Endes, Z.; Er, F. Physical and chemical properties of some seed and kernel oils. Asian J. Chem. 22, 6531-6536(2010).

26) Aued-Pimentel, S.; Takemoto, E.; Antoniassi, R.; Badolato, E.S.G. Composition of tocopherols in sesame seed oil: an indicative of adulteration. Grasas y Aceites 57, 205-210(2006). 